\title{
Acceptance of methods of family planning in patients undergoing repeat cesarean section
}

\author{
Priyanka Upmanyu' ${ }^{1}$, Anjali Kanhere ${ }^{2 *}$
}

\begin{abstract}
${ }^{1}$ Department of Obstetrics and Gynecology, PCMS \& RC, Bhopal, Madhya Pradesh, Pin 462037, India
${ }^{2}$ Department of Obstetrics and Gynecology, CMCH, Bhopal, Madhya Pradesh, Pin 462044, India
\end{abstract}

Received: 09 March 2016

Accepted: 14 March 2016

\section{*Correspondence:}

Dr. Anjali Kanhere,

E-mail: kanhereanju@yahoo.com

Copyright: ( $)$ the author(s), publisher and licensee Medip Academy. This is an open-access article distributed under the terms of the Creative Commons Attribution Non-Commercial License, which permits unrestricted non-commercial use, distribution, and reproduction in any medium, provided the original work is properly cited.

\begin{abstract}
Background: The increasing number of cesarean sections is a leading cause of repeat cesarean section. This leads to a significant increase in risk factor for future obstetric morbidity and at times mortality in form of unintended pregnancy, over the counter use of medical abortion pills and other complications. In India, $65 \%$ of women in the first year postpartum have an unmet need for family planning. The traditional paradigm of starting contraception at a woman's $6^{\text {th }}$ week postpartum visit has been revolutionized, as the emphasis is shifting to providing women with the most effective methods as soon as possible in postpartum. This study is done to find out the acceptance of methods of family planning in patients undergoing repeat cesarean section.

Methods: Prospective longitudinal study for a period of one year in patients undergoing cesarean section at Department of Obstetrics and Gynecology at PCMS \& RC, Bhopal.

Results: During the study period 48 patients underwent repeat cesarean section after recruitment and counseling for the methods of family planning. The mean age was 28.03 years. Majority of the patients $26(64.17 \%)$ were in the age group of 23 to 28 years. $29(60.42 \%)$ were gravida 2, parity 1. Although $100 \%$ patients were inclined to use some method of family planning, $33(68.75 \%)$ accepted long term method of contraception in form of permanent method tubectomy $23(47.92 \%)$ and 10 (20.94\%) PPIUCD. The acceptance rate for use of long term method of contraception was significantly high in booked patients $27(56.25 \%)$.

Conclusions: This study reveals good knowledge and favorable attitude of women towards contraception who are undergoing a repeat cesarean section. The acceptance of method of choice for family planning in patients undergoing repeat cesarean section is still permanent method in form of tubal ligation. Immediate post placental IUD insertion at the time of cesarean delivery is safe and acceptable. This can be used as alternate long term contraceptive method with antenatal counseling.
\end{abstract}

Keywords: Methods of family planning, Repeat cesarean section, Tubal ligation, PPIUCD

\section{INTRODUCTION}

India is the second largest country in the world accounting for $17.5 \%$ of world's population. On First March 2011, Indian's population stood at 1.21 billion which is projected to be 1.4 billion in 2026. ${ }^{1}$ The increasing number of cesarean sections is a leading cause of repeat cesarean section. This leads to a significant increase in risk factor for future obstetric morbidity and at times mortality in form of unintended pregnancy, over the counter use of medical abortion pills and other complications. In India, $65 \%$ of women in the first year postpartum have an unmet need for family planning. ${ }^{2}$ The common reasons for unmet need are lack of information, and fear about side effects of contraceptive method. Studies show that pregnancies taking place within 24 months of previous birth have higher risk of adverse outcome like abortion, premature labour, postpartum 
hemorrhage, low birth weight babies, fetal loss, and maternal death. More than one half of these unmet need pregnancy end in termination. Quite a large number-to stress upon the critical need for those women who do not desire pregnancy, to be aware of and have access to the various methods of safe and effective contraception.

Women are highly motivated and receptive to accept Family planning (FP) methods during the postpartum period. $^{4}$ The traditional paradigm of starting contraception at a woman's $6^{\text {th }}$ week postpartum visit has been revolutionized, as the emphasis is shifting to providing women with the most effective methods as soon as possible in postpartum. ${ }^{3}$ Family planning can reduce maternal mortality by reducing the number of pregnancies, the number of abortions, and the proportion of births at high risk. ${ }^{5,6}$

This study is done to find out the acceptance of methods of family planning in patients undergoing repeat cesarean section.

\section{METHODS}

\section{Study design}

This was a prospective longitudinal type of study which was conducted during 01 May 2014-31 May 2015, in Department of Obstetrics and gynecology PCMS \& RC, Bhopal MP

\section{Study population}

All immediate postpartum LSCS patients with history of previous CS. Questionnaire based counseling and interview of patients in antenatal OPD in last trimester who were planned to undergo LSCS was done. Acceptance or rejections of methods of family planning, age, parity, family size, education, choice of other contraceptive methods were studied as variables. Inclusion criteria All elective LSCS patient with history of previous CS, counseled, consented for the study. Exclusion Criteria LSCS for complicated indications.

\section{RESULTS}

During the study period 48 patients underwent repeat cesarean section after recruitment and counselling for the methods of family planning. The mean age was 28.03 years. Majority of the patients $26(64.17 \%)$ were in the age group of 23 to 28 years (Table 1). $29(60.42 \%)$ patients were gravida 2, parity 1 (Table 2).

Most of the patients $32(65 \%)$ were educate above senior secondary level. The numbers of patients accepting long term method of contraception were 33 (68.75\%) (Table 3).

Although $100 \%$ patients were inclined to use some method of family planning (Table 4), 33 (68.75\%) accepted long term method of contraception in form of permanent method tubectomy $23(47.92 \%)$ and 10 $(20.94 \%)$ PPIUCD. Short term method was of choice in $15(31.26 \%)$ patients. The method of choice was barrier and injectable method of contraception. None of the patient opted for progesterone only pill (Table 5).

The acceptance rate for use of long term method of contraception was significantly high in booked patients 27(56.25\%) (Table 6).

Table 1: Number of patients of various age groups who accepted family planning.

\begin{tabular}{|ll|}
\hline Age group (yrs) & No. of patients \\
\hline $20-22$ & $3(6.25 \%)$ \\
\hline $23-25$ & $12(25 \%)$ \\
\hline $26-28$ & $14(29.17 \%)$ \\
\hline $29-31$ & $8(16.67 \%)$ \\
\hline $32-35$ & $8(16.67 \%)$ \\
\hline$>35$ & $3(6.25 \%)$ \\
\hline Total & 48 \\
\hline
\end{tabular}

Table 2: Numbers of patients of different gravida status who accepted family planning.

\begin{tabular}{|ll|}
\hline Gravida status & No. of patients \\
\hline Primigravida & $0(0 \%)$ \\
\hline Second gravida & $29(60.42 \%)$ \\
\hline Third gravida & $12(25 \%)$ \\
\hline Fourth gravida & $6(12.5 \%)$ \\
\hline Fifth gravida & $1(2.08 \%)$ \\
\hline
\end{tabular}

Table 3: Numbers of patients with different education levels who accepted family planning.

\begin{tabular}{|ll|}
\hline Level of education & No. of patients \\
\hline Upto $5^{\text {th }}$ grade & $2(4.17 \%)$ \\
\hline Upto $8^{\text {th }}$ grade & $5(10.42 \%)$ \\
\hline Secondary/10 & $9(18.75 \%)$ \\
\hline Senior secondary $/ 12^{\text {th }}$ & $11(22.92 \%)$ \\
\hline Graduate & $17(35.42 \%)$ \\
\hline Post graduate & $4(8.33 \%)$ \\
\hline
\end{tabular}

Table 5: Acceptance of contraception.

\begin{tabular}{|ll|}
\hline Acceptance of contraception & No. of patients \\
\hline Yes & $48(100 \%)$ \\
\hline No & Nil \\
\hline
\end{tabular}

Table 6: Method of contraception.

\begin{tabular}{|ll|}
\hline Method of contraception & No. of patients \\
\hline Abstinence & $0(0 \%)$ \\
\hline Barrier & $14(29.17 \%)$ \\
\hline Progesterone only pills & Nil \\
\hline Injectable contraceptive & $1(2.08 \%)$ \\
\hline PPIUCD & $10(20.84 \%)$ \\
\hline Tubectomy & $23(47.92 \%)$ \\
\hline
\end{tabular}


Table 4: Various family planning methods opted by patients of different education grade.

\begin{tabular}{|llllll|}
\hline Level of education & PPIUCD & Tubectomy & Barriers & DMIPA & Total numbers of couples \\
\hline $5^{\text {th }}$ grade & Nil & Nil & 2 & Nil & 2 \\
\hline $8^{\text {th }}$ grade & 1 & 3 & 1 & Nil & 5 \\
\hline $10^{\text {th }}$ grade & 2 & 4 & 3 & Nil & 9 \\
\hline $12^{\text {th }}$ grade & 2 & 5 & 4 & Nil & 11 \\
\hline Graduate & 3 & 10 & 4 & Nil & 17 \\
\hline Post graduate & 2 & 1 & Nil & 1 & 4 \\
\hline
\end{tabular}

Table 7: Choice of contraception in couples who were booked or unbooked in antenatal period.

\begin{tabular}{|lllll|l|}
\hline & PPIUCD & Tubectomy & Barrier & Injectable & \\
\hline Booked & $8(16.67 \%)$ & $19(39.59 \%)$ & $11(22.92 \%)$ & $1(2.08 \%)$ & 39 \\
\hline Unbooked & $2(4.17 \%)$ & $4(8.34 \%)$ & $3(6.25 \%)$ & NIL & 9 \\
\hline Total & $10(20.84 \%)$ & $23(47.92 \%)$ & $14(29.17 \%)$ & $1(2.08 \%)$ & 48 \\
\hline
\end{tabular}

\section{DISCUSSION}

In Our study $100 \%$ patients were aware of methods of family planning and were aware of their usage. A similar level of awareness was reported by Mathe et $\mathrm{al}^{7}$ in their study on study on 572 post-partum women. The National Family Health Survey 3(8) which found a nearly universal knowledge about contraception included all women from 15-45 years (rural as well as urban).

In our study the higher education status of the women and prenatal counseling were significant predictors of higher level of acceptance of family planning methods of contraception. Association of higher education status with knowledge and use of contraception has been observed by other authors in their studies. ${ }^{4,9,10}$ Some authors have observed that the decision for use was also significantly affected by the women's level of education. ${ }^{9}$

$60 \%$ were under 28 yrs. of age and were being operated second time as a case of repeat Cesarean section. Repeated cesarean sections are related to more severe maternal and fetal complications compared to the first cesarean birth. $^{11}$

The intrauterine device is an effective long lasting and reversible method of birth control. ${ }^{4,12}$ The insertion of IUCDs is now gaining popularity as a method of postpartum contraception worldwide. The Indian Government is also focusing programmatic attention to postpartum IUCD insertion. Immediate post placental IUCD insertion (PPIUCD) during caesarean section provides a good opportunity to achieve long term contraception with minimal discomfort to the women. ${ }^{13}$ It is being increasingly practiced after reported safety and lower expulsion rates following intracaesarean IUCD insertion.

In our study 10 patients $(20.84 \%)$ choose this as a method of contraception. $23(47.92 \%)$ patients opted for permanent method of contraception as single sitting tubal ligation procedure along with cesarean section. In other study by Maier $\mathrm{K}^{14}$ tubal ligation was the method of choice in $23 \%$ patients after cesarean section. The American College of Obstetricians and Gynecologists has recognized the importance of providing timely postpartum permanent contraception and quotes a $51 \%$ repeat pregnancy rate within 1 year of delivery. Women who request postpartum tubal ligation must have prenatal counseling. In our study the acceptance rates for use of long term method of contraception was significantly high in booked patients $27(56.25 \%)$ undergoing repeat cesarean section.

\section{Limitations}

The study represents a small number of patients.

\section{CONCLUSIONS}

This study reveals good knowledge and favourable attitude of women towards contraception who are undergoing a repeat cesarean section. The acceptance of post-partum intrauterine contraceptive device is low than permanent method in this study as awareness among the women for use of PPIUCD during cesarean section is a new start. Higher education status and prenatal counselling are significant predictors of higher rate of acceptance.

Correct promotion provided cesarean section patients in a traditional environment accept contraceptives and are interested in family planning. Immediate post placental IUD insertion at the time of cesarean delivery is safe and acceptable. This can be used as alternate long term contraceptive method with antenatal counselling.

\section{ACKNOWLEDGEMENTS}

The authors would like to thank the institute and the department for their support. We would also like to thank the patients for their participation and cooperation. 
Funding: No funding sources

Conflict of interest: None declared

Ethical approval: The study was approved by the Institutional Ethics Committee

\section{REFERENCES}

1. India at glance-population census 2011. Census organization of India, 2011. Available at: http://censusindia.gov.in/2011-

provresults/indiaatglance.html. Accessed on 1 January 2014

2. Ross JA, Winfrey WL. Contraceptive use, intention to use and unmet need during the extended postpartum period international family planning perspectives. Int Fam Plann Persp. 2001;27(1):20-7s.

3. Speroff L, Mishell DR Jr. The postpartum visit: it's time for a change in order to optimally initiate contraception. Contraception. 2008;78(2):90-8.

4. Kanhere AV, Pateriya P, Jain M. Acceptability and feasibility of immediate postpartum IUCD insertion in a tertiary care centre in Central India. Int J Reprod Contracept Obstet Gynecol. 2015;4:179-84.

5. Levine R, Langer A, Birdsall N, Matheny G, Wright M, Bayer A. Contraception. In: Jamison DT, Breman JG, Measham AR, eds. Disease Control. Priorities in developing countries. $5^{\text {th }}$ ed. New York: Oxford University Press; 2006:1075-1090.

6. Lule E, Singh S, Chowdhury SA. Fertility regulation behaviors and their costs: contraception and unintended pregnancies in Africa and Eastern Europe \& Central Asia. In: Lule E, Singh S, Chowdhury SA, eds. A Report. Washington DC, USA: HNP Publication, World Bank; December 2007.
7. Mathe JK, Kasonia KK, Maliro AK. Barriers to adoption of family planning among women in eastern democratic republic of Congo. Afr J Reprod Health. 2011;15(1):69-77.

8. International Institute for Population Sciences (IIPS) and Macro International. National family health survey (NFHS-3), 2005-06: India. In: IIPS, eds. IIPS Survey. 2007;1(5):111-3.

9. Kanojia JK, Nirbhavane NC, Toddywala VS, Betrabet SS, Patel SB, Datte S et al. Dynamics of contraceptive practice amongst urban Indian women. Natl Med J India. 1996;9(3):109-12.

10. Hernandez LE, Sappenfield WM, Goodman D, Pooler J. Is effective contraceptive use conceived prenatally in Florida? The association between prenatal contraceptive counseling and postpartum contraceptive use. Matern Child Health J. 2012;16(2):423-9.

11. Makoha FW, Felimban HM, Fathuddien MA, Roomi F, Ghabra T. Multiple cesarean section morbidity. Int J Gynaecol Obstet. 2004;87:227-32.

12. Postpartum IUCD reference manual, New Delhi: family planning division, ministry of health and family welfare, government of India. 2010.

13. Kapp N, Curtis KM. Intrauterine device insertion during the postpartum period: a systematic review. Contraception. 2009;80(4):327-36.

14. Maier K, Wacker J, Bastert G. Family planning and desire for additional children after cesarean section. Int J Gynaecol Obstet. 1993;41(1):81-4.

Cite this article as: Upmanyu P, Kanhere A. Acceptance of methods of family planning in patients undergoing repeat cesarean section. Int J Reprod Contracept Obstet Gynecol 2016;5:976-9. 